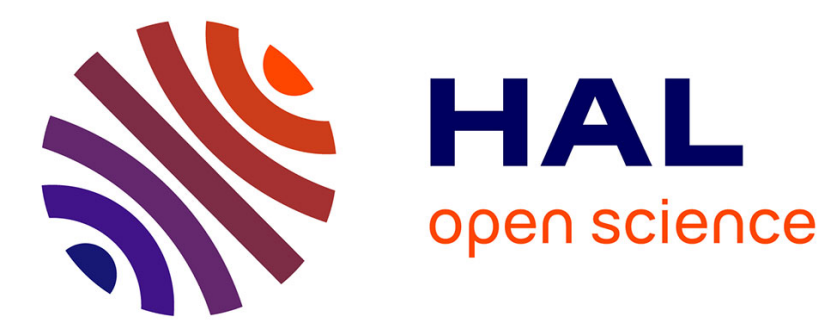

\title{
The invader, the enemy within and they-who-must-not-be-named: how police talk about minorities in Italy, the Netherlands and France \\ François Bonnet, Clotilde Caillault
}

\section{- To cite this version:}

François Bonnet, Clotilde Caillault. The invader, the enemy within and they-who-must-not-be-named: how police talk about minorities in Italy, the Netherlands and France. Ethnic and Racial Studies, 2015, 38 (7), pp.1185-1201. 10.1080/01419870.2014.970566 . hal-01076723

\section{HAL Id: hal-01076723 \\ https://hal.science/hal-01076723}

Submitted on 22 Oct 2014

HAL is a multi-disciplinary open access archive for the deposit and dissemination of scientific research documents, whether they are published or not. The documents may come from teaching and research institutions in France or abroad, or from public or private research centers.
L'archive ouverte pluridisciplinaire HAL, est destinée au dépôt et à la diffusion de documents scientifiques de niveau recherche, publiés ou non, émanant des établissements d'enseignement et de recherche français ou étrangers, des laboratoires publics ou privés. 


\title{
The invader, the enemy within and they-who-must-not-be-named. How police talk about minorities in Italy, the Netherlands and France
}

\author{
Francois Bonnet and Clotilde Caillault \\ Published in Ethnic and Racial Studies, DOI: 10.1080/01419870.2014.970566 \\ http://www.tandfonline.com/doi/full/10.1080/01419870.2014.970566\#.VEevVBYvf14
}

\begin{abstract}
How people talk about ethnic minorities is a sensitive subject, especially in law enforcement. We know little about it as far as continental Europe is concerned. This article is about how police officers talk about minorities in France, in Italy and in the Netherlands. How do speech norms ("political correctness") apply outside the Anglophone world? Is there a relation between speech norms and practices? This exploratory study is based on interviews with 55 police officers from France, Italy and the Netherlands. In these countries, police officers are aware that displaying overt racism is not socially desirable. Interviews show that there are vastly different speech norms governing decent race talk in the three countries. Specifically, we compare: how police use ethnic categories; how police anticipate accusations of discrimination; and how police theorize the over-representation of ethnic minorities in crime. French respondents respect much stricter speech norms than Dutch or Italian ones.
\end{abstract}

Key words

Police, Racism, Social desirability, Speech, Discourse, Europe

\section{Introduction}

In most countries, social groups - often construed as ethnic groups-become the main suspects of police activity: African Americans in the United States, "Caucasians" (from the Caucasus) in contemporary Russia and Roma people in Continental Europe. They have been called "police property", the "dangerous classes", the "symbolic assailant", and so on. This article does not set out to demonstrate that these targeted minorities commit less or more crime than the majority, it is about how police officers talk about them in France, Italy and the Netherlands.

How people talk about race is a sensitive subject, because of the moral condemnation of racism. For instance, in the aftermath of the Stephen Lawrence inquiry, police organizations in the United Kingdom have prohibited racial slurs (Foster et al., 2005). Strict non-racist speech norms regarding race are a fact of life in much of the Anglophone world (Eliasoph, 1996; Pollock, 2004). The folk concept of "political correctness" has sought to capture the set of social norms that governs discourse about race (Fairclough, 2003). This issue is of special concern within law enforcement, as police officers are often suspected of engaging in profiling and discrimination (Reiner, 2010, pp. 128-131).

How do speech norms apply outside the Anglophone world? We know less about Continental Europe than we do about North America and the United Kingdom, where "political correctness" is a much-discussed notion. This is why the article examines France, Italy and the Netherlands. What is at stake here is the relation between speech norms and how police 
interact with minorities. Police-minority relations are a central topic in race research and raise questions of social justice (Brunson and Miller, 2006; Carr, Napolitano and Keating, 2007; Hasisi and Weitzer, 2007; Sharp and Atherton, 2007).

This exploratory study is based on interviews with 55 police officers from France, Italy and the Netherlands. In these three countries, police officers are aware that displaying overt racism is not socially acceptable. Interviews show that there are vastly different speech norms governing acceptable race talk in the three countries. Specifically, we compare: how police use ethnic categories; how police anticipate accusations of discrimination; and how police theorize the over-representation of ethnic minorities in criminal activity.

\section{Racism as a category of practice}

In contemporary public space and social science, racism is the object of strong and nearuniversal disapproval. In the past twenty years, public opinion research in the United States has found fewer respondents willing to endorse racist views (Schuman et al., 1997). In many Western democracies, overt racist speech is publicly reviled and there are legal statutes criminalizing racist speech and discrimination, or aggravating punishment for hate crimes (Bleich, 2011). Political parties - even those of the extreme right, whose appeal largely rests on racial resentment - vehemently object to being labeled as racist (Mudde, 2007). Within corporations, human-resources divisions have to care about diversity in the workplace (Dobbin and Sutton, 1993). In everyday life, this translates into a social world where people do not want to appear racist.

This context leads to two intellectual routes. The first uses critical discourse analysis to reveal closeted racism. This is the project of Teun van Dijk (1992), implemented by, among others, Bell and Hartmann (2007), Bonilla-Silva (1997, 2006), Myers and Williamson (2001) and Zamudio and Rios (2006), which aims to study discourse and to show how hesitations, contradictions, inconsistencies and nervous laughs are evidence of inner racism. Discourse analysis allows us "to delve beneath the surface of initial answers to reach the deep structure and cultural commonsense" (Bell and Hartmann, 2007, p. 898). A key assumption of these authors is that racism is a category of analysis (a scientific concept).

The second route rests on a different premise: following Brubaker and Cooper (2000) and Wacquant (1997), it conceptualizes racism as a category of practice. Instead of looking for evidence of inner racism in people's speech patterns, this article sets out to compare how similar actors in three different countries speak about race and minorities, to document different speech norms around race talk. By comparing speech norms in France, Italy and the Netherlands, we are looking into different regimes of speech norms, and ultimately different conceptions of what is racist or not.

We answer two research questions. (1) Is there cross-national variation in speech norms? Openly racist speech has become deviant in Anglophone countries. What is the situation in Western Europe? We may hypothesize that different histories of race and migration may produce different speech norms. Societies with a longer history of racial relations (non-white immigration, colonial past and an involvement in slavery) may be more likely to develop stricter speech norms. (2) How important are speech norms? Speech norms may be interesting in their own right, but their practical consequences matter. In particular, is there a relation between speech norms and police-minority relations? Two competing hypotheses may answer this question. On the one hand, critical discourse analysis assumes that speech reveals deeper attitudes which, in turn, translate into practices. On the other hand, Waddington (1999) 
treats police speech as "expressive talk", e.g. disconnected from practices and largely irrelevant to the study of actual police-minority relations.

\section{Research design: making use of the social desirability bias}

To reveal speech norms, our methodological strategy is to make use of the social desirability bias. Social desirability means that respondents know that some attitudes or behaviors are more desirable than others, and they will tend to distort their answers to be perceived more favorably (Philips and Clancy, 1972). Social desirability bias has been used to explain why, depending on context, people over- or under-report their religiosity, income, party affiliations or achievements. Social desirability is usually perceived as a methodological obstacle, because it makes data less reliable. Scholars are thus looking for ways to "overcome" the social desirability bias (Pager and Karafin, 2009; Pager and Quillian, 2005) by utilizing participant observation (Shapira, 2013), audit studies (Pager and Quillian, 2005) or interviews (Blauner, 1989).

Our research design is based on the assumption that we can make the social desirability bias work to our advantage in order to reveal regimes of speech norms (Bonnet, 2014). Interviews create an artificial setting where people have to manage social desirability concerns. In our case, how police talk about minorities, racism, profiling and discrimination reflects prevailing (but contextual) speech norms (Bonnet 2014). We are not interested in what officers "really" or "privately" think: what matters to us is "what they are supposed to say to a stranger".

To demonstrate that speech norms are contextual, we have interviewed a total of 55 police officers and security personnel in three Western European countries: France, Italy and the Netherlands.

- 32 police officers in France, two sites in the Paris region (second author, interviews in French). 6 respondents out of 38 were female, 7 were minority, and the respondents' mean age was 33 .

- 12 officers in the Netherlands, two sites in the Amsterdam region (second author, interviews in English). One respondent was female and another one was minority, with a mean age of 33 .

- 11 persons in Italy, two sites in the Milan region, including 4 police officers and 7 private security personnel (first author, interviews in Italian). All respondents were male, one was from a minority, with a mean age of 39.

We conducted research in two waves. In 2004, the first author did a comparative study of policing at four sites in France and Italy. In 2011, the second author did a comparative study of policing in France and the Netherlands, under the supervision of the first author. This article is based on the first author's Italian data and the second author's French and Dutch data.

Comparability is ensured because the two sites in each country are located in the largest urban area, which maximizes ethnic diversity; in each country, one site was located in a poorer, higher crime neighborhood than the other site. On each site, we received authorization to contact police officers in two precincts, and we interviewed as many volunteers as we could. This sampling method does not guarantee randomness, but was imposed by circumstances. We did not compensate respondents. We guaranteed confidentiality. Interviews took place at the precinct station and lasted from 45 to 90 minutes. Interviews in France and the Netherlands were recorded, transcribed and inductively coded (Glaser and Strauss, 1967) with the support of the Atlas.ti software. Respondents in Italy did not allow audio recording. The 
researcher took as many handwritten notes as possible during the interview, then completed the notes as soon as the interview was over, and transcribed the notes fully. We selected the quotes that said most eloquently what most other officers were saying.

In each country, we have interviewed our respondents about their daily work: what they have done today and yesterday; what types of concerns they have to worry about; who they interact with, and for what types of concern; who they work with, and what they think of possible partners. We have avoided discussing race overtly; we sought to avoid a situation where informants would have to articulate their folk theory of racism. We believe such research to be more likely to result in artifacts. We chose to let conversations organically develop towards criminal activity of minorities, so as to be able to document how police officers talk without being primed by our choice of words. Our research design works like a quasi-experiment; we ask the same questions to the same people, and we put them in a similar situation: that of speaking of race and crime, which should trigger the social desirability bias. Our findings are based on the contrast between how these similar people speak about race, racism and minorities in different countries.

Our sample of France, Italy and the Netherlands allows us to answer our first research question (variability of speech norms) because these countries are not Anglophone and each represents a different style of Western European society (Arts and Gelissen, 2002; EspingAndersen, 1990). In this typology, Anglophone countries exemplify the residual welfare state. France is representative of corporatist states alongside countries like Germany or Belgium. Italy is representative of Southern European (Mediterranean) states like Spain or Greece. The Netherlands are representative of social-democratic states like Scandinavian countries.

Regarding our second research question (relation between speech norms and police-minority relations), the sample introduces two variables. One is the different colonial and immigration histories. France and the Netherlands have been colonial empires, deeply involved in the slave trade, and have been countries of immigration for decades-since the late $19^{\text {th }}$ century in France (Weil, 1991) and the 1950s in the Netherlands (Vasta, 2007). Italy is a case of more recent immigration, with Albanians, Romanians, Moroccans and Chinese immigrants arriving since the 1990s (Pittau and Forti, 2004). The other variable is racial tensions related to policing. The frequency of riots in France suggests that relations between minorities and the police are very poor (Body-Gendrot and Wihtol de Wenden, 2003; Fassin, 2011; Open Society Institute, 2009; Pager, 2008). The Dutch and Italian cases are relatively less contentious.

This research design has limitations. First, the interviews were performed by French interviewers in France, Italy and the Netherlands, possibly putting Dutch and Italian respondents in a different position to that of French respondents. Dutch respondents were interviewed in English. We believe these limitations to be inconsequential, because other studies done by Dutch and Italian scholars in their respective countries point towards similar speech patterns (Dal Lago, 1999; Dal Lago and Quadrelli, 2003; Pakes, 2004; Quassoli, 1999). Second, it has been difficult to gain access to Italian police officers, and our Italian data are based on a case study of plural policing, hence the presence of private security personnel. Because we have found public and private officers' speech patterns to be remarkably similar, and because our findings are coherent with Italian scholarship, we think that this limitation is manageable. Third, the unrepresentativeness of the sample prevents us from generalizing our findings. Systematic research with multiple sites across each country, and with a larger number of respondents, would certainly reveal regional variations in speech norms, and internal variations in the observance of speech norms. Yet, such a study would prove costly and difficult 
to organize, as police organizations, notably in France and Italy, are reluctant to cooperate with social research. Because of these limitations, we see this study as exploratory in design, aimed at formulating hypotheses to be tested systematically.

\section{Ethnic categories as awkward and muted (France) or explicit and commonsense (Italy, Netherlands)}

Before going into the specifics of how police officers from different countries discuss race and ethnicity, we may first inquire as to whether the mere fact of speaking about ethnicity is unproblematic or awkward. In this section, we document how using ethnic categories is uneasy in France, and how it is casual in Italy and the Netherlands.

French respondents categorically and adamantly deny that the very category of color, ethnicity or race may play a role in their police work. No matter how the subject is approached, respondents seem to feel personally attacked or judged, and become defensive. French police officers are extremely concerned with anticipating and avoiding potential accusations of racism, and such a direct association of ethnicity with crime typically violates French speech norms. These speech norms are manifest when one considers the awkwardness with which French officers talk about ethnicity when they have to.

Question: Are foreigners subjected to more police stop-and-checks? I ask because there is a lot of debate about that in the Netherlands.

French police officer: Well no, not at all. Me, I do identity checks on request [abbreviation from legal lexicon], me, I check everyone, that's it. I can't stand it, as far as I am concerned. (...) we check everybody and for instance there are many more men than women who are arrested, that's crazy, there are also women who do wrong stuff. There're also women who drive without a license, there're also women who beat up their spouse. They're much less checked. Minorities will feel more persecuted whereas us... Eventually it's when we try to... but how many times have I been called a racist. Me, it gets on my nerves, something crazy, but me it gets on my nerves, but we are called racists, [voicing an imaginary dialogue] "you racists", "but Sir, do you know why we stopped you?", "yes for my mug”, "well no Sir, your turn right, you forgot your turn signal"

The first theme of this quote is the concern about racism. When the respondent says "I can't stand it", he certainly means (unmade) accusations of racism. The respondent is outraged at being (implicitly) accused of racism, which ostensibly underlines his personal abhorrence of racism. Second, the lack of casualness in speaking about criminal activity among minorities is manifest in the broken structure of expression, hesitations, silences, and indignation, which we do not analyze as evidence of inner, hidden racism, but as evidence that such a topic is sensitive and controversial. Casual references to minorities as criminals undoubtedly sound racist in France. Third, the respondent is asked about racial profiling, and switches to the safer topic of gender imbalance in policing, implicitly saying that his understanding of "minorities" goes beyond "ethnic" minorities and extends to different type of minorities, such as women. This shows how French police officers may be reluctant to speak about ethnicity. This obviously does not mean that police "really" are colorblind, as research has consistently suggested (Body-Gendrot and Wihtol de Wenden, 2003; Fassin, 2011; Open Society Institute, 2009; Pager, 2008).

This defensiveness contrasts with Dutch and Italian officers. Many Dutch police officers make unequivocal associations between bad places, criminals and foreigners - or allochtonen. Allochtoon, often a short form of "non-western allochtoon", is the Dutch way to refer to 
ethnic minorities in the public space. It is a mostly uncontroversial word that is used by politicians of all persuasions and social scientists alike; only progressive social scientists object to its use (RMO, 2012; Vasta, 2007).

Dutch police officer 8: In this area, there are bad 'allochtonen'. I mean outside, not among the colleagues, but on the streets, the public... Not every 'allochtoon' is bad, but the most troubles on the street, when you talk about theft, robbery... most of the time, it's an 'allochtoon'. And that is very strange because there are 15 million Dutch people, most people are 'autochtoon', and if you go to jail, most criminals are 'allochtonen'.

Dutch respondents express clear-cut attitudes towards specific ethnic groups, especially Moroccans. Most respondents make a clear association between (presumed) Moroccans and crime, and our respondents sometimes referred to Moroccans as "kut Marokkanen" ("fucking Moroccans") or "kanker Marokkanen" ("this cancer that are Moroccans"). In practice, police officers often associate Moroccans with other groups. A much broader range of groups is potentially affected by the stereotypes described above: Turkish, Kurdish, Middle Eastern, and other North Africans. Police officers also stereotype Poles as criminal, but Moroccans are the focus of their concerns - they have replaced Surinamese, who used to be considered the dangerous minority by Dutch police officers in the 1970s (Punch, 1976).

Question: Here everybody talks about Moroccans, why?

Dutch police officer 10: It's like a disease, I guess the whole community of that people, 90 per cent is wrong, 10 per cent is ok, people that want to work, the same who want to be the same as the Dutch people. When you watch the news on television or some programs, we call it 'Opsporing Verzocht' it's a program it's every Monday, Tuesday, you have the robberies and the criminals from the week before that and most are people from Morocco. And when you get an emergency call from dispatch, mostly it's people from Morocco.

A simple way to ascertain the sensitivity of a given topic is to listen to the small talk that fills space before or after more formal semi-structured interviews with sociologists-for instance, in the Netherlands, where one of us was casually asked by a police officer of Surinamese origin:

Dutch officer: Do you have specific types of people that cause trouble in France?

Researcher: What do you mean?

Dutch officer: Like, here we have the Moroccans; they cause a lot of problems.

Similarly, in Italy, ethnic categories are part of everyday conversations.

Italian security guard 1: Of course, knowing languages helps, I speak French, we have a new coworker who speaks English, it's very convenient, and at the supermarket, they have a guy who speaks German.

Italian head of security 1 [interrupting]: But they've never caught a German! [everybody laughs]

The comic twist of the joke lies in the understatement, "They've never caught a German"; Germans are not supposed to commit thefts, unlike, in the Italian context, Albanians, Romanians, or French- or English-speaking Africans. French respondents may privately share similar jokes, but they avoid doing so publicly. Italian respondents are straightforward in their designation of immigrants as problems and see no interactional problem in speaking about ethnicity. 
Italian head of security 2: In Rome, we have a beautiful bright train station, but outside, in the two closest streets, it's neglected and deteriorated. You'll find all possible ethnic groups that will come and create troubles.

In Italy, the explicit designation of immigrants is not a controversial issue, whether in public space or during an interview. In the Milan train station, law-enforcement personnel speak of security problems by constantly referring to the presence of immigrants.

Italian police officer 1: For thefts, we've had another increase, because of Albanians and Romanians who have arrived. They don't deal drugs, I mean, some deal drugs, but then above all, they steal. There are also thefts with violence. Thefts that are not linked with drugs, they are mostly done by Slavs.

For law-enforcement personnel, ethnic categorization is conveyed through an association that Italian sociologists call immigrazione uguale criminalità, immigration = crime: "all the interviewees use national categories to describe the simplest crimes" (Quassoli 1999, p. 47). Given nationalities become metonymies for given crimes.

Italian police officer 2: 90 per cent of arrests concerns foreigners. They share the work: North-Africans deal drugs, Algerians and French ones, who are in fact former Algerians and have Algerian features, they steal. Chileans, South-Americans only steal but they are intelligent. Romanians do a bit of everything, they steal, they deal drugs. (...) Romanians are a plague, since the economical agreements, you don't need visas, half of the crimes are done by Romanians. [He points at the records]

Italian respondents are different from Dutch ones. "Moroccans" in the Netherlands typically are not immigrants, but second generation; they typically hold Dutch citizenship. Dutch "Moroccans" are construed as an ethnicity, not as a nationality. Ethnic framing is not absent from Italian discourse, as the reference to "French ones, who are in fact former Algerians" suggests. But in Italy, Romanians and Albanians hold Romanian and Albanian passports; because most immigration into Italy is relatively recent (Pittau and Forti, 2004), there is not yet a second generation. Police officers therefore perceive them as foreign legal subjects and identify them as such. Italian and Dutch respondents speak openly about minorities. On the contrary, French discourse on ethnic groups is characterized by "colorblindness", which is the denial of the relevance of color, ethnicity or race in making sense of the world (Bird, 2000; Bleich, 2011; Brubaker, 2001). Race is a sensitive topic and French police officers do not speak casually about it (Lévy and Zauberman, 2003).

\section{Anticipating accusations of discrimination (or not)}

Casualness and awkwardness when speaking about ethnicity translate into different modalities of concern over the accusation of discrimination.

Italian respondents are virtually indifferent to a possible accusation of racism. In Italy, immigrants and minorities are often called "extracommunautarians", a word that means "immigrant not from the European Union". Asked about security problems in her mall, the general manager casually answers: "We have extracommunautarians but they stay quiet." Assuming such an automatic relation between immigrants and trouble would be a deviance to French speech norms.

This contrasts with the Dutch case, where officers say they are accused of racism, and where there are rising concerns over ethnic profiling (van der Leun and van der Woude, 2011; Amnesty International, 2013). 
Dutch officer 3: There are only one or two minorities that don't respect the police. For example, Moroccans, they don't like the police at all, but the police don't like Moroccans too, so... (...) It comes from their... you know, the first Dutch word they learn is "oh you are a racist" because you are a white girl, you get a fine for driving through a red light, for example, I write a fine to you, you say, "ok, I don't like it, but thank you" and I say "have a nice day", but I write exactly the same fine to a Moroccan guy or girl, they say "hey, this is because I'm from Morocco, [mocking an Arab accent] blablabla", exactly the same.

In this quote, accusations are immediately dismissed in a contemptuous manner ("the first Dutch word they learn is 'oh you are a racist"'). According to Dutch officers, it is widely known, and non-controversial to say it, that Moroccans commit more crime than Dutch autochtonen. Dutch police officers do not see themselves as racist and profess that they treat all offenses equally, even when they mock an Arab accent, which would be shockingly racist in France.

Consider the French defense against the accusation of discrimination.

French officer 15: ... on certain types of public that always feel victimized, that have the impression of being always checked. But once again, they play on it. If they are checked, it's because there is something wrong. They don't wear their seatbelt, they have committed an offence, they drive too fast, so there is always a reason for the check, it's not for fun. We are checking because there is something fishy, in a way.

Minorities (unnamed as such) "feel victimized", as opposed to being the victim of discrimination. But, in the officers' logic, there cannot be discrimination, since officers are colorblind. The legitimacy of arrests is taken for granted: if the police arrest someone, there must be a legitimate reason, for French police officers are proud enforcers of the law.

French officer 9: what do you mean, discrimination?! What does that mean?! The offender has no color (...) Oh yes, "you only stop blacks and Arabs" no, no. (...) For me, the job how I see it, it is 'crime has no color'. It is my motto. I can deal with an Arab, a black or a white, or a green, a Martian, for me, it's the same.

Most French respondents categorically rejected the idea that the ethnicity or the color of a person could influence their judgment in any way. French police officers insist that being objective and fair precisely means the avoidance of ethnic categories. This is in stark contrast with Italian and Dutch officers, who perceive the criminal world through these categories and do so openly and in a non-controversial manner. French police officers say they only act "according to the facts", that is, according to the nature and the seriousness of the offense committed. In this perspective, discrimination is nothing but a subjective, mistaken perception, made by citizens (abstract citizens) who are not able to understand the value of police work, or are prejudiced against the police.

Note the difference between the three types of discourse: Italian respondents are virtually indifferent to a potential accusation of racism, and speak freely about criminal activity of minorities; Dutch police officers also speak freely about criminal activity of minorities (in ways that would be labeled as racist in a French context), but they are not indifferent to a potential accusation of discrimination, which they discard by arguing about the overcriminality of minorities - a move that would be considered racist in France; French respondents are extremely concerned about avoiding an accusation of racism in the ways they speak about minorities, and they defend themselves against the potential accusation of 
discrimination by emphasizing the objectiveness and strict legality of their work and the ostensible belief that ethnic categories are irrelevant to their cognitive processes.

\section{Theorizing minority crime: cultural (Italy, Netherlands) and structural explanations (France)}

In this section, we look at the theories that police officers mobilize to make sense of the overrepresentation of minorities in criminal activity. For Dutch and Italian officers, culture explains minority crime, while French interviewees favor structural explanations.

Consider this Italian police officer, a white male in his forties, talking about Chinese and Moroccan immigrants. Chinese immigrants in Milan are not considered a criminal problem, whereas Moroccans are. For this officer, their respective cultural otherness best explains their different behavior.

Italian police officer 2: [The Chinese] have their own neighborhoods, their own laws. If they steal from each other, they won't go to the police to press charges. They settle it down among themselves. They have a different language, a different culture. None of them would collaborate with us, they are incredible and they are all the same. (...) Chinese people are incredible. You don't hear anything from them because there isn't a particular crime committed by the Chinese. (...) For Milanese people, Chinese people are not a threat, whereas Moroccans are, it's in their culture, they slash up their faces with their knives, you'll always see that. These are different cultures. Europeans have houses which they always more or less keep neat. The Moroccan guy, he always lives in his dirt, he has another relation to cleanliness, and I am not saying that out of racism! But they are dirty, they never wash their dishes, they let it pile up. (Police officer, Italian train station)

For this Italian police officer, it is in the culture of Chinese immigrants to solve criminal matters within the Chinese community without interference from the Italian judicial institutions, just as it is in the culture of Moroccan immigrants to slash their faces with knives and generally indulge in crime. In the Netherlands, Dutch police officers also emphasize cultural themes to explain the tensions they experience with Moroccans. Many police officers put forward the fact that Moroccans "don't want to adapt" to Dutch culture and society.

Dutch officer 3: I think that in France, you have the same problem with Algerian people. Why do always Moroccans or Algerians have a problem? I think, they don't want to integrate in the new country. If I go to Morocco, on holiday for example, I have to listen and I have to adapt myself to their culture, I have to wear long trousers, I cannot look at their women, I was in Iraq so I know how it works, never show your left foot to a Muslim, don't wave with your left hand because it's not clean, you know, that is the basic rules in Muslim culture. So when I go to a Muslim country, I try to adapt myself to the Koran, maybe not to the Koran but to the Muslims as much as possible. So when a Muslim comes to our country, he has to know how it works in our country because for example we can look at other women, we can sit like this [legs wide open], you can see my foot sole, when I see someone I say "hey" with my left hand, it's all this kind of little things are little differences but when a guy from Morocco comes to my country and expects from me that I adapt to him, I think that is wrong.

This type of argument is widespread in Dutch public debate, but only since the 2000s, following the publication of a newspaper article called "The Multicultural Tragedy" by sociologist Paul Scheffer, and the murders of populist politician Pim Fortuyn in 2002 and director Theo van Gogh in 2004 (Pakes, 2004; van Eijk, 2010; Vasta, 2006). Right-wing 
politicians often criticize Moroccans for not showing enough good will in assimilating to Dutch society, and publicly doubt that Moroccans can assimilate at all, because of their culture and adherence to Islam, which is considered by Dutch populist parties as a generally backwards religion whose core values are antithetical to the Dutch liberal tradition of tolerance. In the same way, Dutch respondents also refer to the 2005 French riots, which they interpret as the confirmation of a cultural problem with North Africans.

French respondents give different arguments to explain the overrepresentation of ethnic groups in crime statistics. Many French police officers favor what sociologists would call a structural explanation.

French officer 6: But it's true that... and I'm really quite objective, unfortunately... I mean... people with an immigrant background, they are in social housing, they are the ones that have less money, and they are the most disadvantaged, so necessarily it's an unstoppable logic. There is no, there is not... It's inevitable, crime is going to come from where, it's coming from these people. Without being... I'm not especially left wing or right wing, I'm nothing at all. It seems to me that it's an unstoppable logic. When we hear left wing people, they say there is discrimination but it's not true at all. Society makes what it's going to be of these people. That's it, so it will be immigration from Africa, from North Africa, that's all. We will find these people. Now there are many Eastern countries because it's them who come here. But it's not especially... It's how it goes, that's it. It's the unhappy people, who steal, who... That's all. And unhappy people, who is it now: it's the immigrants. I'm not especially, nothing, but it's the unstoppable logic, like it must be everywhere, like in the US, they say minorities, the Latinos, yes because the Latinos, maybe they work in a factory, on the assembly line, they are penniless, they can't get decent housing, so at some point to escape all that, there is one of them that is going to, maybe sell some drugs, there is no... It's society that wants it.

According to this police officer, crime is a matter of social problems rather than culture: migrants and ethnic minorities are over-represented in crime statistics because of the "unstoppable logic" of social problems: poverty, spatial relegation and the resulting discontent explain why immigrants and minorities offend more. Note how important it is for our French respondent to avoid political labeling: promoting a structural explanation for crime (which may sound progressive in the French political context), he takes pain to criticize "leftwing people" for blaming alleged discriminatory police practices. This quote is also a good example of the uneasiness with which French respondents talk about what they consider to be a sensitive topic: the many hesitations, unfinished sentences, and repetitions contrast with the straightforward casualness of their Dutch and Italian counterparts.

\section{The invader, the enemy within and they-who-must-not-be-named}

Our research design cannot allow for systematic inferences, but may be helpful to draw a typology that will need further testing. French, Italian and Dutch police officers differ in several ways in how they discuss minorities and what it reveals of their relationships. Table 1 typifies our results and provides the number of respondents for each country who fit the speech norms pattern that we have documented (n/a's refer to interviews in which our main concern was not discussed).

\begin{tabular}{|l|l|l|l|}
\hline Item & France & Netherlands & Italy \\
\hline $\begin{array}{l}\text { Explicit designation of } \\
\text { minorities }\end{array}$ & No & Yes & Yes \\
\hline
\end{tabular}




\begin{tabular}{|c|c|c|c|}
\hline $\begin{array}{l}\text { Minorities construed as ethnic } \\
\text { groups vs. foreigners }\end{array}$ & Ethnic groups & Ethnic groups & Foreigners \\
\hline $\begin{array}{l}\text { Concerned with accusations of } \\
\text { racism }\end{array}$ & Yes & Yes & No \\
\hline $\begin{array}{l}\text { Over-criminality of minorities is } \\
\text { a legitimate argument }\end{array}$ & No & Yes & Yes \\
\hline $\begin{array}{l}\text { Cultural or structural } \\
\text { explanation of crime }\end{array}$ & Structural & Cultural & Cultural \\
\hline $\begin{array}{l}\text { Total number of respondents } \\
\text { fitting the documented national } \\
\text { pattern }\end{array}$ & $\begin{array}{l}\text { Fit: } 24 \\
\text { Deviant: } 2 \\
\text { n/a: } 6 \\
\text { Total: } 32\end{array}$ & $\begin{array}{l}\text { Fit: } 9 \\
\text { Deviant: } 1 \\
\text { n/a: } 2 \\
\text { Total: } 12\end{array}$ & $\begin{array}{l}\text { Fit: } 9 \\
\text { Deviant: } 0 \\
\text { n/a: } 2 \\
\text { Total: } 11\end{array}$ \\
\hline $\begin{array}{l}\text { Including number of } \\
\text { minority respondents } \\
\text { fitting the pattern }\end{array}$ & $\begin{array}{l}\text { Fit: } 6 \\
\text { n/a: } 1 \\
\text { Total: } 7\end{array}$ & $\begin{array}{l}\text { Fit: } 1 \\
\text { Total: } 1\end{array}$ & $\begin{array}{l}\text { Fit: } 1 \\
\text { Total: } 1\end{array}$ \\
\hline
\end{tabular}

Table 1: Summary of results

France is a country that is often opposed to the Anglophone world, and the United States in particular, for its "universalist" take on conceptions of citizenship and race (Brubaker, 2001). Our data reveal that France is very similar to the Anglophone world in its strict observance of speech norms governing race talk. French respondents seem to be affected by "political correctness": they are concerned about appearing racist, and they speak carefully to avoid that accusation. Minorities in France are "they-who-must-not-be-named": unspeakable but often on the mind. In the Netherlands, "Moroccans" actually are construed as an ethnic group, a threat to the cultural unity of the Kingdom, a problem that can be discussed openly and without infringing speech norms. Moroccans are the "enemy within" the Netherlands. In Italy, the concern for accusations of racism is less prevalent because minorities are not thought of (yet?) as ethnic groups, because they are still foreigners. Italian officers arrest people with a foreign passport, as opposed to nationals with a distinct ethnic identity. This is a fundamental difference with the Dutch case, with which the Italian one, otherwise, resembles. Immigrants are therefore more likely to be perceived as "invaders".

\section{Conclusion}

Our analysis raises a number of observations. The first one, regarding our first research question, is that there are important variations in speech norms. French officers respect strict speech norms, while Dutch and Italian officers use language that would seem appalling in the Anglophone world. In effect, the discursive construction of the "symbolic assailant", of the bad minority, is country-specific. "Arabs" (Algerians, Moroccans and Tunisians), West Africans and Roma people in France; Romanians, Albanians, Moroccans and Roma people in Italy; Moroccans and Poles in the Netherlands: there is an element of diversity in this list where skin color ("race" in the United States) is not the mother of all "racial" categorization. The distinctions we have made in our typology add to the scholarship that warns against the uncritical projections of American conceptions of race onto other realities (Bourdieu and Wacquant, 1999).

The second observation is that Dutch and Italians are racist by French standards, but they are not racist by Dutch and Italian standards. The national definition of what is racist varies more than many may expect. In the Anglophone world, strict non-racist speech norms regarding race are expected of any somewhat-developed country. Openly racist discourse (by French or Anglophone standards) may be perceived as evidence of racial backwardness. But such 
reasoning only applies by using racism as a category of analysis, an objective standard by which any country can be judged, with French and Anglophone activists arguing over the respective merits of colorblind and race-conscious conceptions of non-racism. Seen from a Dutch perspective, or an Italian perspective, how Dutch and Italians speak about minorities would not be perceived as "racist" in polite society. Of course, there are many academics and activists, both in the Netherlands and Italy, who are working to change speech norms, partly under the influence of Anglophone conceptions of what is racist discourse and what is not (for instance, Palidda, 2011). How these norms circulate, through which venues, and how they are reinterpreted locally, should be studied more systematically.

A consequence of that - our third observation-is to ask why different countries have different conceptions of what is racist and what is not. Our research design is unable to answer that question. But assuming that the speech patterns we have documented are not local artifacts (an assumption that is consistent with the literature), we observe that there is no simple structural explanation that fits. France and Italy are fairly different when it comes to the amount and timing of immigration, but France and the Netherlands both have similar numbers of immigrants, who arrived within similar time frames; they both were colonial empires; the three countries collaborated with Nazi Germany to perpetrate the Holocaust. The only factors that seem explanatory are the idiosyncrasies of national public spheres and the development of national models of citizenship (Brubaker, 1992).

Finally, and this is our fourth point, regarding our second research question: it is widely assumed within the social sciences that discourse matters, but the variations in discourse we observe are mostly inconsequential when it comes to practice. Strict non-racist speech norms do not translate into non-racist policies. Chronic rioting in France, almost systematically triggered by an event of police misconduct, suggests that French speech norms do not cause minority-friendly policies-just as British or American speech norms do little to prevent racialized outcomes in policing and sentencing. Strict non-racist speech norms may be a worthy endeavor, but they are a long way from changing actual policies that systematically impair the life chances of minorities.

\section{Acknowledgments}

We are grateful for the useful feedback from Laura Boschetti, Francesco Ragazzi, Guillaume Roux and Clément Théry. This paper has been financially supported by the SPACECONTROL project (ANR no ANR-10-ESVS-001-01), at Maison européenne des sciences de l'homme et de la société (MESHS - USR 3158).

\section{Bibliography}

Amnesty International. 2013. Proactief politieoptreden vormt risico voor mensenrechten. Etnisch profileren onderkennen en aanpakken. Retrieved on February 6, 2014, http://www.amnesty.nl/sites/default/files/public/rapport_etnisch_profileren_ainl_2 8_okt_2013.pdf.

Arts, W., and J. Gelissen. 2002. "Three worlds of welfare capitalism or more? A state-of-theart report". Journal of European Social Policy, 12 (2): 137-158.

Bell, Joyce M., and Douglas Hartmann. 2007. "Diversity in Everyday Discourse: The Cultural Ambiguities and Consequences of 'Happy Talk"'. American Sociological Review, 72 (6): 895-914. 
Bird, Karen L. 2000. "Racist Speech or Free Speech? A Comparison of the Law in France and the United States". Comparative Politics, 32 (4): 399-418.

Blauner, Robert A. 1989. Black Lives, White Lives: Three Decades of Race Relations in America. Berkeley: University of California Press.

Bleich, Erik. 2011. The Freedom to be Racist? How the United States and Europe Struggle to Preserve Freedom and Combat Racism. Oxford: Oxford University Press.

Body-Gendrot, Sophie, and Catherine Wihtol de Wenden. 2003. Police et discriminations raciales: le tabou français. Paris: Editions de l'Atelier.

Bonilla-Silva, Eduardo. 1997. "Rethinking Racism: Toward a Structural Interpretation". American Sociological Review, 62 (3): 465-79.

Bonilla-Silva, Eduardo. 2006. Racism Without Racists (Second Edition). Lanham: Rowman and Littlefield.

Bonnet, François. 2014, "How to Perform Non-Racism? Colorblind Speech Norms and RaceConscious Policies among French Security Personnel", Journal of Ethnic and Migration Studies, 40 (8), pp. 1275-1294

Bourdieu, P., and L. Wacquant. 1999. "On the cunning of imperialist reason". Theory, Culture \& Society, 16(1): 41-58.

Brubaker, Rogers. 1992. Citizenship and Nationhood in France and Germany. Cambridge, Mass.: Harvard University Press.

Brubaker, Rogers. 2001. "The return of assimilation? Changing perspectives on immigration and its sequels in France, Germany and the United States". Ethnic and Racial Studies, 24 (4): 531-548.

Brubaker, Rogers and Frederick Cooper. 2000. "Beyond Identity". Theory and Society, vol. 29: $1-47$.

Brunson, Rod K. and Jody Miller. 2006. "Young Black Men and Urban Policing in the United States". British Journal of Criminology, 46(4):613-640.

Carr, Patrick J., Laura Napolitano and Jessica Keating. 2007. "We Never Call the Cops and here is why: A Qualitative Examination of Legal Cynicism in Three Philadelphia Neighborhoods". Criminology, 45(2): 445-480.

Dal Lago, Alessandro and Emilio Quadrelli. 2003. La città e le ombre, Milan: Feltrinelli

Dal Lago, Alessandro. 2004. Non-persone. L'esclusione dei migranti in una societa globale, Milan: Feltrinelli.

Dobbin, F., Sutton, J. R., Meyer, J. W., and Scott, R. 1993. "Equal opportunity law and the construction of internal labor markets". American Journal of Sociology, 396-427.

Eliasoph, Nina. 1996. "Making a Fragile Public: A Talk-Centered Study of Citizenship and Power", Sociological Theory, 14 (3): 262-289.

Esping-Andersen, G. 1990. The Three Worlds of Welfare Capitalism. Oxford: Polity Press.

Fairclough, N. 2003. “'Political correctness': The politics of culture and language”. Discourse \& Society. 14 (1): 17-28.

Fassin, Didier. 2011. La force de l'ordre. Paris: Seuil.

Foster, J., Newburn, T., and Souhami, A. 2005. Assessing the impact of the Stephen Lawrence inquiry. London: Home Office. 
Hasisi, Badi and Ronald Weitzer. 2007. "Police Relations with Arabs and Jews in Israel". British Journal of Criminology, 47 (5):728-745.

Lévy, René, Renée Zauberman. 2003, "Police, minorities and the French republican ideal", Criminology, 41 (4): 1065-1100.

Mudde, Cas. 2007. Populist radical right parties in Europe. Cambridge: Cambridge University Press.

Myers, Kristen and Passion Williamson. 2001. "Race Talk: The Perpetuation of Racism Through Private Discourse", Race \& Society, vol. 4: 3-26.

Open Society Institute. 2009, Profiling Minorities: A Study of Stop-and-Search Practices in Paris. Open Society Justice Initiative, http://www.opensocietyfoundations.org/sites/default/files/search_20090630.Web. pdf.

Pager, Devah. 2008. "The Republican Ideal? Ethnic Minorities and the Criminal Justice System in Contemporary France". Punishment and Society, 10(4): 375-400.

Pager, Devah and Diana Karafin. 2009. "Bayesian Bigot? Statistical Discrimination, Stereotypes, and Employer Decision-Making". Annals of the American Academy of Political and Social Sciences, n ${ }^{\circ}$ 621(January): 70-93.

Pager, Devah and Lincoln Quillian. 2005. "Walking the Talk? What Employers Say Versus What They Do". American Sociological Review, 70 (3): 355-380.

Pakes, F. 2004. "The politics of discontent: The emergence of a new criminal justice discourse in the Netherlands". The Howard Journal of Criminal Justice, 43(3): 284-298.

Palidda, Salvatore (Ed.) 2011. Racial Criminalisation of Migrants in the $21^{\text {st }}$ Century. Ashgate Publishing.

Phillips, D. L., and K. J. Clancy. 1972. "Some effects of 'social desirability' in survey studies”. American Journal of Sociology, 77 (5): 921-940.

Pittau, Franco, and Oliviero Forti. 2004. "Italia, paese di immigrazione : tra flussi regolari e irregolari”, Studi Emigrazione/Migration Studies, XLI (153): 157-168.

Pollock, Mica. 2004. Colormute. Race Talk Dilemmas in an American School, Princeton, NJ: Princeton University Press.

Punch, Maurice. 1976. "Frontline Amsterdam: Policework in the Inner City", British Journal of Law and Society, 3 (2): 218-232.

Quassoli, Fabio. 1999." Immigrazione uguale criminalità. Rappresentazioni di senso commune e pratiche organizzative degli operatori del diritto", Rassegna Italiana di Sociologia, 40 (1): 43-76.

Reiner, Robert. 2010. The Politics of the Police. $4^{\text {th }}$ ed.. Oxford: Oxford University Press

RMO (Raad voor Maatschappelijke Ontwikkeling). 2012, Tussen afkomst en toekomst, Etnische categorisering door de overheid, retrieved on http://content1c.omroep.nl/f88683dadc7a42cb896440bf83c642b5/50851da5/nos/d ocs/080512_tussen_afkomst_en_toekomst.pdf.

Schuman, Howard, Charlotte Steeh, Lawrence Bobo, and Maria Krysan. 1997. Racial Attitudes in America: Trends and Interpretations. $2^{\text {nd }}$ ed. Cambridge: Harvard University Press. 
Shapira, Harel. 2013. "From the Nativist's Point of View. How Ethnography Can Enrich Our Understanding of Political Identity". The Sociological Quarterly, 54 (1), 35-50.

Sharp, Douglas and Susie Atherton. 2007. "To Serve and Protect? The Experiences of Policing in the Community of Young People from Black and Other Ethnic Minority Groups". British Journal of Criminology, 47(5): 746-763.

van der Leun, J. P., and M. A. van der Woude 2011. "Ethnic profiling in the Netherlands? A reflection on expanding preventive powers, ethnic profiling and a changing social and political context". Policing and Society, 21(4): 444-455.

Van Dijk, Teun A. 1992. "Discourse and the denial of racism". Discourse \& Society, 3 (1): 87-118.

Van Eijk, G. 2010. "Exclusionary policies are not just about the "neoliberal city': a critique of theories of urban revanchism and the case of Rotterdam". International Journal of Urban and Regional Research, 34(4): 820-834.

Vasta, Ellie. 2007. "From ethnic minorities to ethnic majority policy: Multiculturalism and the shift to assimilationism in the Netherlands". Ethnic and Racial Studies, 30 (5): 713-740.

Wacquant, Loic J.D. 1997. "For an Analytic of Racial Domination", Political Power and Social Theory, vol. 11: 221-234.

Waddington, P.A.J. 1999. "Police (Canteen) Subculture. An Appreciation". British Journal of Criminology, 39 (2): 287-309.

Weil, Patrick. 1991. La France et ses étrangers. Paris: Calmann-Lévy.

Zamudio, Margaret M., and Francisco Rios. 2006. "From Traditional Racism to Liberal racism: Living Racism in the Everyday". Sociological Perspectives, 49 (4): 483501.

FRANCOIS BONNET is Assistant Research Professor at CNRS (Pacte) - University of Grenoble Alpes.

ADDRESS: UMR Pacte, Institut d'études politiques, BP 48, 38040 Grenoble cedex 9, France. Email: francois.bonnet@iepg.fr

CLOTILDE CAILLAULT holds a Master's degree from the Department of Sociology and Anthropology at the University of Amsterdam.

ADDRESS: Department of Sociology and Anthropology, Universiteit van Amsterdam, Nieuwe Achtergracht 166, 1018 WV Amsterdam, The Netherlands. Email: clotilde.caillault@gmail.com 